increase the difficulties of those doctors who are unable to use A4 files.

A4 files used as described above are not sent on when a patient leaves the practice list. Instead letters are removed, folded, and placed with the record cards in the original record envelope for onward transfer. The A4 file is re-used for an incoming patient. The patient's name and essential identification details can be recorded on the front of the file using adhesive labels. The file itself should not be used to record information on an individual patient in any way that would prevent its re-use for another patient.

The modified use of A4 files offers an interim solution at a time when a decision concerning the general introduction of A4 records is awaited.

The background data cards and the patient questionnaire were developed with the generous help of the Cardew-Stanning Foundation.

"Starter packs" of the background data cards and patient questionnaires together with the handbook with example cards may be obtained free from the Cardew Stanning Foundation, 6 Arlington Street, London W1. The cards may also be obtained in any quantity on a commercial basis from F W Pawsey and Son, Dale Road, Ipswich, Suffolk.

(Accepted 26 fuly 1977)

\title{
Arterial embolism in thyrotoxicosis with atrial fibrillation
}

\author{
J S STAFFURTH, MARGARET C GIBBERD, S NG TANG FUI
}

British Medical fournal, 1977, 2, 688-690

\begin{abstract}
Summary
In 262 patients with thyrotoxicosis and atrial fibrillation, there were 26 episodes of arterial embolism (17 cerebral and nine elsewhere) in 21 patients. Twelve incidents occurred with active thyrotoxicosis, three on reversion to sinus rhythm, and 11 after the patients were euthyroid.

This important complication is more common than is realised, and most patients should be put on prophylactic anticoagulants when first seen with atrial fibrillation.
\end{abstract}

\section{Introduction}

Systemic arterial embolism from the left atrium is a common complication of atrial fibrillation (AF), particularly when associated with mitral valve disease. ${ }^{12}$ The occurrence of arterial emboli when AF complicates thyrotoxicosis, however, has received surprisingly little comment. We report 26 episodes of systemic arterial occlusion (considered to be due to emboli) in 21 patients with $\mathrm{AF}$ due to thyrotoxicosis.

\section{Patients}

From 1958 to 1976 we treated 845 thyrotoxic patients with radioactive iodine of whom $238(28 \%)$ had had AF confirmed by electrocardiography at some stage in the course of their disease. Many were referred by physicians from neighbouring hospitals. There were also 24 patients with $\mathrm{AF}$ who had had a subtotal thyroidectomy. One other patient (case 14) seen in a different context is also included. The diag-

Lewisham Hospital, London SE13 6LH

J S STAFFURTH, MD, FRCP, physician

MARGARET C GIBBERD, MRCP, clinical assistant

S NG TANG FUI, MRCP, medical registrar nosis of thyrotoxicosis was confirmed by a combination of the various biochemical investigations currently in use and standard radioactive iodine $\left({ }^{131} \mathrm{I}\right)$ uptake tests.

\section{Results}

The patients who had emboli fell into three groups: (1) 11 with active thyrotoxicosis and AF at the time of the embolus, (2) three who had reverted to sinus rhythm immediately before the episode, and (3) 10 with persistent AF after they had become euthyroid.

Group 1 (see table I) consisted of 11 patients, five of whom had a cerebral embolus, five an embolus in a limb, and one both. All had active thyrotoxicosis at the time, and in eight the arterial occlusion was the presenting feature. Three were known to have reverted to sinus rhythm with an antithyroid drug during a previous episode of thyrotoxicosis. During the period under review there were seven other thyrotoxic patients with AF who had an arterial occlusion, but in these another cause for the vascular lesion was more likely. These included four with severe hypertension, two with recent myocardial infarction, and one with carotid artery stenosis.

One patient (case 1) deserves fuller description: a woman aged 55 years was admitted in 1955 with a sudden left hemiplegia from which she made a good recovery. She had severe thyrotoxicosis with cardiac failure and AF, which had probably developed two months previously. Two months after starting carbimazole she reverted to sinus rhythm. Carbimazole was continued for two years, but six weeks after it was stopped AF recurred with a severe relapse of thyrotoxicosis. She was given $10 \mathrm{mCi}^{131} \mathrm{I}$ elsewhere in 1957 with only partial improvement. One year later she was readmitted to hospital with a popliteal artery embolus and persistent thyrotoxicosis and AF. Two further doses of ${ }^{131} \mathrm{I}$ in the next four months cured the thyrotoxicosis, but AF persisted, and two years later she had another disabling hemiplegia.

Group 2 comprised three patients in whom an embolus occurred shortly after reversion to sinus rhythm (table II). The most dramatic (case 12) had a transient right hemiplegia the day after successful cardioversion, AF having been present for three years. Case 14 had had a thyroidectomy elsewhere 10 years before when a right hemiplegia occurred shortly after reversion to sinus rhythm and unfortunately severe disability has persisted.

Group 3 comprised 10 patients (table III) in whom eight episodes of cerebral embolism and three of an arterial embolism elsewhere occurred from two months to 10 years after the patients were euthyroid. Three of these patients had had an embolus previously when actively thyrotoxic. We also know of seven other patients with persistent AF 
TABLE I-Active thyrotoxicosis

\begin{tabular}{|c|c|c|c|c|c|}
\hline \multirow{2}{*}{ Case No } & \multirow{2}{*}{ Sex Age } & \multicolumn{2}{|c|}{ When first diagnosed } & \multirow{2}{*}{ Site of embolism } & \multirow{2}{*}{ Comments } \\
\hline & & Thyrotoxicosis & $\mathrm{AF}$ & & \\
\hline $\begin{array}{r}1 \\
2 \\
3 \\
4 \\
5 \\
6 \\
7 \\
8 \\
9 \\
10 \\
11\end{array}$ & 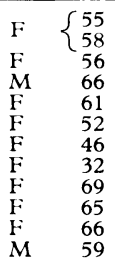 & $\begin{array}{l}\text { On admission } \\
3 \text { years } \\
1 \text { month } \\
\text { On admission } \\
4 \text { years } \\
6 \text { years } \\
\text { On admission } \\
9 \text { years } \\
6 \text { months } \\
\text { On admission } \\
\text { ? } 7 \text { years }\end{array}$ & $\begin{array}{l}\text { On admission } \\
3 \text { years } \\
1 \text { month } \\
\text { On admission } \\
4 \text { years } \\
4 \text { years } \\
\text { On admission } \\
\text { On admission } \\
6 \text { months } \\
\text { ? } \\
\text { On admission } \\
3 \text { years }\end{array}$ & $\begin{array}{l}\text { (M) Cerebral } \\
\text { (M) Left popliteal } \\
\text { (M) Cerebral } \\
\text { (M) Cerebral } \\
\text { (T) Cerebral } \\
\text { (T) Cerebral } \\
\text { (T) Cerebral } \\
\text { (T) Popliteal } \\
\text { (T) Popliteal } \\
\text { (M) Popliteal } \\
\text { (S) Femoral } \\
\text { (T) Brachial }\end{array}$ & $\begin{array}{l}\text { Reverted to SR on carbimazole } \\
\text { Relapse of thyrotoxicosis (see case summary) } \\
\text { Relapse thyrotoxicosis then diagnosed } \\
\text { AF twice reverted to SR before final cure } \\
\text { Temporary reversion to SR with carbimazole after first dose of }{ }^{131} \mathrm{I} \\
\text { Successful embolectomy }\end{array}$ \\
\hline
\end{tabular}

$\mathrm{AF}=$ Atrial fibrillation. $\mathrm{SR}=$ Sinus rhythm. $\quad \mathrm{T}=$ Transient. $\quad \mathrm{M}=$ Moderate. $\mathrm{S}=$ Severe.

TABLE II-Embolism, on reversion to sinus rhythm

\begin{tabular}{|c|c|c|c|c|c|}
\hline Case No & & & How long in SR & Site of embolism & Comments \\
\hline $\begin{array}{l}12 \\
13\end{array}$ & $\stackrel{F}{F}$ & $\begin{array}{l}52 \\
79\end{array}$ & $\begin{array}{l}1 \text { day } \\
<1 \text { week }\end{array}$ & $\begin{array}{l}\text { (T) Cerebral } \\
\text { (T) Cerebral }\end{array}$ & $\begin{array}{l}\text { After successful cardioversion } \\
\text { Also left bundle-branch block and mitral incompetence. Reversion to SR occurred while still } \\
\text { thyrotoxic }\end{array}$ \\
\hline 14 & F & 60 & $<2$ weeks & (S) Cerebral & Still severely dysphasic 10 years after thyroidectomy. \\
\hline
\end{tabular}

$\mathrm{SR}=$ Sinus rhythm. $\quad \mathrm{T}=$ transient $. \quad \mathrm{M}=$ moderate. $\mathrm{S}=$ severe.

TABLE III-Euthyroid, persistent atrial fibrillation

\begin{tabular}{|c|c|c|c|c|}
\hline Case No & Sex Age & Time euthyroid & Site of embolism & Comments \\
\hline $\begin{array}{r}1 \\
2 \\
9 \\
15 \\
16 \\
17 \\
18 \\
19 \\
20 \\
21\end{array}$ & 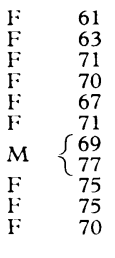 & $\begin{array}{l}1 \text { year } \\
5 \text { years } \\
3 \text { years } \\
2 \text { years } \\
3 \text { months } \\
1 \text { year } \\
2 \text { years } \\
10 \text { years } \\
3 \text { years } \\
2 \text { years } \\
1 \text { year }\end{array}$ & $\begin{array}{l}\text { (S) Cerebral } \\
\text { (M) Cerebral } \\
\text { (M) Cerebral } \\
\text { Cerebral (fatal) } \\
\text { (M) Cerebral } \\
\text { (M) Cerebral } \\
\text { (T) Cerebral } \\
\text { (S) Brachial } \\
\text { (T) Cerebral } \\
\text { (M) Popliteal } \\
\text { Superior mesenteric } \\
\text { (fatal) }\end{array}$ & $\begin{array}{l}\text { Remained permanently disabled } \\
\text { No necropsy } \\
\text { Died suddenly with persistent AF } 3 \text { years later } \\
\text { Reverted to SR } 6 \text { months later } \\
\text { Successful embolectomy }\end{array}$ \\
\hline
\end{tabular}

$\mathrm{AF}=$ Atrial fibrillation. $\mathrm{SR}=$ Sinus rhythm. $\mathrm{T}=$ Transient. $\quad \mathrm{M}=$ Moderate. $\mathrm{S}=$ Severe.

who had a cerebrovascular accident when euthyroid. All had severe hypertension and probably their strokes were due to cerebral haemorrhage or thrombosis.

\section{Discussion}

In an individual patient with $\mathrm{AF}$ it is often difficult to be sure whether a cerebrovascular accident has been caused by an embolus, particularly in an older patient with hypertension, though it is usually assumed that a sudden arterial occlusion in a limb is embolic. We believe that emboli were the cause of all the 26 incidents reported here. On the other hand, in 10 other thyrotoxic patients with a cerebrovascular accident seen during the same period it is more likely that an embolus was due to a cause other than $\mathrm{AF}$, or cerebral infarction was due to severe associated hypertension.

None of our patients with active thyrotoxicosis died, and the immediate prognosis was good in all 12 instances. This may have been because patients who died were not referred to us, for emboli may be fatal, and two of our euthyroid patients in group 3 died. Parker and Lawson ${ }^{3}$ reported 33 deaths from thyrotoxicosis in Scotland in one year, eight of whom had major emboli and seven others died suddenly from unstated reasons; other fatalities have also been recorded. ${ }^{4-10}$

Surprisingly, little attention is paid by physicians to this important complication. As we have continued to see patients since we first commented on the association, ${ }^{10}$ we think that others are not aware of the frequency, possibly because of the divided care of patients, as so many are referred to special centres for radioactive iodine treatment. Many large series of patients with $\mathrm{AF}$ and thyrotoxicosis have been reviewed without any mention of possible embolism, though often "cerebrovascular accident" is given as a late cause of death, ${ }^{11-16}$ and none of the current standard thyroid, endocrine, or cardiac textbooks discuss the possibility.

On the other hand, others, particularly surgeons of the previous generation, have commented on the risk and emphasised the importance of early reversion to sinus rhythm. In a series of 1400 patients with thyrotoxicosis Levitt ${ }^{8}$ found that 155 had $\mathrm{AF}$, of whom nine $\left(6^{\circ}{ }^{\circ}\right)$ had arterial emboli. In 254 patients with AF treated surgically, Hudson ${ }^{9}$ had four fatalities from embolism coincident with the establishment of normal rhythm.

In an unpublished series of 42 patients with thyrotoxicosis and AF Davies ${ }^{17}$ had eight cerebral and three peripheral emboli in nine patients. From the neurological aspect Carter, ${ }^{1}$ using strict diagnostic criteria, reported 123 patients with cerebral embolism, eight of whom had AF due to thyrotoxicosis, but he did not state whether or not this was active at the time. Numerous other isolated incidents have also been reported, yet in a recent authoritative book on cerebrovascular disease it is stated that "it is notable that atrial fibrillation occurring with thyrotoxicosis rarely causes embolism." 18

Besides the risk of embolism, AF undoubtedly is disadvantageous in respect of cardiac function and life span, ${ }^{101920}$ so that greater consideration should be given to the prompt and permanent reversal to sinus rhythm. In our total series of 262 patients with AF 14 had reverted to sinus rhythm on antithyroid 
drugs in a previous episode of thyrotoxicosis, only to develop AF again when they relapsed, ${ }^{21}$ and two of them had a cerebral embolus in the relapse. Thus we believe strongly that all thyrotoxic patients with AF should have curative treatment when first diagnosed.

If $\mathrm{AF}$ persists when the patients are euthyroid we consider that younger ones ( $<65$ years) should be offered external cardioversion, for this has been effective with great symptomatic benefit for at least one year in 15 out of 25 of our patients. One patient had a minor stroke after successful defibrillation, a hazard that has long been recognised with quinidine, ${ }^{9}$ and may occur after external cardioversion for $\mathrm{AF}$ from any cause. ${ }^{2:}$ Full anticoagulation should be used as a routine before this is attempted.

It is not general usage to put thyrotoxic patients with AF on anticoagulants, but in view of these findings we consider that most patients and certainly all younger ones should be anticoagulated when AF is first diagnosed and that this should be continued until they are euthyroid and have reverted to sinus rhythm, spontaneously or after cardioversion. For those with persistent AF long-term anticoagulants will be a matter for individual judgment but generally they are not advised in the elderly or those with hypertension, nor in patients who are known to have had AF for a long time. Any patient who has had one embolus must certainly be anticoagulated indefinitely if AF persists, for second episodes are common and have occurred in six of our patients.

\section{References}

1 Carter, A B, Lancet, 1965, 2, 514

2 Wood, P, British Medical fournal, 1951, 1, 1051.

${ }^{3}$ Parker, J W L, and Lawson, D H, Lancet, 1973, 2, 894.

4 Willius, F A, and Boothby, W M, Medical Clinics of North America, 1923, 7, 189.

${ }^{5}$ Hurxthal, L M, American Fournal of the Medical Sciences, 1930, 179, 507.

${ }^{6}$ Jervell, A, Acta Medica Scandinavica, 1952, suppl No 266, p 585.

- Rundle, F F, Foll's Diseases of the Thyroid. London, Heinemann, 1951.

${ }^{8}$ Levitt, T, The Thyroid. Edinburgh, Churchill Livingstone, 1954.

${ }^{9}$ Hudson, R V, Proceedings of the Royal Society of Medicine, 1959, 52, 810.

10 Staffurth, J S, Gibberd, M C, and Hilton, P J, Postgraduate Medical fournal, 1965, 41, 663 .

11 Magee, H R, and Smith, H L, American fournal of the Medical Sciences, 1935, 189, 683.

12 Maloof, F, and Chapman, E M, fournal of Clinical Endocrinology, 1951, 11, 1296.

13 Cookson, H, British Medical fournal, 1959, 1, 244.

14 Sandler, G, and Wilson, G M, Quarterly Fournal of Medicine, 1959, 28, 347

15 Silver, S, Delit, C, and Eller, M, Progress in Cardiovascular Disease, 1962 5,64 .

${ }^{16}$ McGirr, E M, Thomson, J A, and Murray, I P C, Scottish Medical fournal, 1964, 9, 505.

17 Davies, J V S A, personal communication, 1971

18 Russell, R R, Cerebral Arterial Disease. Edinburgh, London, and New York, Churchill Livingstone, 1976.

19 Davis, P J, and Davies, F B, Medicine, 1974, 53, 161.

2" $\mathrm{Ng}$ Tang Fui, S, and Staffurth, J S. To be published.

${ }^{21}$ Gibberd, M C, and Staffurth, J S, personal communication, 1975.

${ }^{22}$ McCarthy, C, Varghese, P J, and Barritt, D W, British Heart fournal, 1969, 31, 496.

(Accepted 12 fuly 1977)
What drugs should be used for treating a urinary tract infection with an ampicillin-resistant organism during pregnancy?

This problem is becoming increasingly common. I find that some $12 \%$ of urinary tract infections are resistant to ampicillin. Some of these resistant infections are sensitive to cephalexin, and I would suggest that despite its high cost this would be the drug to use. If the pathogen is resistant to both penicillins and cephalosporins I would treat infections in pregnancy with a one-week course of either nitrofurantoin ( $50 \mathrm{mg}$ three times a day) or co-trimoxazole ( 2 tablets twice a day). Thereafter the patient should be carefully followed to detect any recurrence. Fears that the trimethoprim component of cotrimoxazole might be teratogenic have not been confirmed. ${ }^{1}$ I would avoid co-trimoxazole in the last trimester because its sulphonamide component might displace bilirubin from its binding site and thus increase the chances of kernicterus in the neonate. ${ }^{1}$ Williams, J D, Kosundis, J, and Geddes, A M, in Current Antibiotic Therapy,
ed A M Geddes and J D' Williams, p 107. Edinburgh and London, Churchil Livingstone, 1973 .

What might be the effect on a healthy young adult of continuous incarceration for two months in a confined cell without exercise and on a diet of uncooked meat and water? Would vitamin deficiency disorders such as scurvy develop in this time?

Physical effects are likely to be slight, since even with food deprivation and no exercise body reserves last for six weeks. On a daily intake of $1 \mathrm{mg}$ vitamin $\mathrm{C}$, which is a tenth of the amount needed for protection against scurvy, it was six months before any changes were noted in healthy volunteers, ${ }^{1}$ and even after 34 weeks there was no anaemia. Even though uncooked meat contains minimal amounts of vitamin $\mathrm{C}$ and granted that stress tends to enhance utilisation, scurvy is unlikely to develop in this time.

${ }^{1}$ Medical Research Council, Lancet, 1948, 1, 853.

Is there any explanation for a woman losing her hair after a normal confinement?

Normally, human hair follicles show asynchronous and intermittent activity. At any one time about $85 \%$ of hairs are in the growing (anagen) phase. Most of the remainder are in a resting (telogen) phase with a very small percentage in a stage of regression (catagen) The circulating hormones of pregnancy seem to delay the onset of the catagen and telogen phases. Parturition then stimulates many follicles to enter catagen simultaneously, and some four to six months later there is a sudden moult of telogen hairs. Patients can be reassured that the hair will regrow within a few months.

I note that in treating scabies benzyl benzoate should not be applied to the head and neck. As scabies in infancy affects the face and head, how are these areas to be treated?

Certainly scabies may affect the head and neck of an infected infant, and these parts should be treated. Unfortunately, benzyl benzoate lotion is irritant to the infant skin, and it may cause considerable stinging, especially if some is rubbed into the eyes. Its use in infants is therefore best avoided. Alternative preparations that are less irritable are gamma benzene hexachloride and monosulfiram. Both should be used according to the makers' instructions; overusage could be dangerous owing to possible systemic absorption.

Now that the Department of Health has pronounced in favour of giving whooping-cough vaccine to children, what should be done for older children - many now nearly 4 years old-not given the vaccine because of the original scare?

This is an important question in view of the predicted increase in the prevalence of whooping cough this winter, and the fact that the preschool child is most often responsible for introducing the infection to babies. The answer must to some extent depend on local policy, and it would seem sensible for each area health authority to make recommendations based on local uptake of whooping-cough vaccine over recent years. My own opinion is that it would be sensible to offer whooping-cough vaccine to as many non-immune preschool children as possible. Discussion with the parents should include an explanation that immunisation of their child will be of great value in protecting vulnerable small babies, especially if there is a baby in the family. We should also remember that, although whooping cough is rarely fatal after infancy, it is still an unpleasant and prolonged disease in older children. 